\title{
$\beta$ - Sitosterol and Betulonic Acid from n-Hexane Extract the Stem Bark of Tetracera indica
}

\author{
Muharni $^{1 *}$, Elfita ${ }^{1}$, Heni Yohandini ${ }^{1}$, Julinar $^{1}$, Muthia Oktaviani ${ }^{1}$ \\ 'Department of Chemistry, Faculty of Mathematics and Natural Sciences, University of Sriwijaya, Indralaya, \\ Oganllir, South Sumatra, 30662 Indonesia
}

*Corresponding author email: muharnimyd@yahoo.co.id

Received March 25, 2019; Accepted October 10, 2019; Available online November 30, 2019

\begin{abstract}
The Tetracera indica has been used traditionally to treat various diseases including skin medications, lower blood pressure, fever, headache, wound and gout medicine. The objective of the research was isolated and characterized the $\beta$-sitosterol (1) and betulonic acid (2) from $n$-hexane extract of the stem bark of Tetracera indica. The dry powder the stem bark $(550 \mathrm{~g})$ was maceration with $n$-hexane for $24 \mathrm{hrs}$. This extraction process was repeated three times. The $n$ hexane extract was separated and purified by chromatography technique. The structure of isolated compound was determined by spectroscopy data UV, IR, NMR and compared with reported data. Two compounds have been isolated and base on spectroscopy data the compounds is $\beta$-sitosterol (1) and betulonic acid (2). Betulonic acid is being reported for the first time from $T$. indica, mean while the $\beta$-sitosterol previously reported from $\mathrm{MeOH}$ extract of leaves of $T$. indica but is being reported for the first time from the stem bark of $T$. indica.
\end{abstract}

Keywords: Betulonic acid, $\beta$-sitosterol, Tetracera indica

\section{INTRODUCTION}

Indonesia is one country of the largest users of medicinal plants in the world along with other countries in Asia, such as China and India (Widjaja et al., 2014). The used of medicinal plants traditionally has been done by Indonesian people for generations. In previous studies, exploration and inventory of medicinal plants and thereused in people local community have been done. One of the medicinal plants is Tetracera indica (Yustian, Muharni, Sukarmi, Zulaicha, \& Arbi, 2012). This species also known by the name Tetracera assay (Hoogland, 1953). The stem bark of $T$ indica was used as a rope and the fruit used as vinegar in cooking. $T$. Indica in Malaysia is known locally name mempelas oil or mempelas rich and in Cina is know locally name caygiaychieu. Malay communities in Malaysia used dry powder of leaves to cure inflammation, while the Temuan Tribe in Selangor used the roots of $T$. indica to treatment of hypertensive patients and high fever. The Machang tribe in Kelantang used mixture the powdered of roots and leaves treat skin diseases (Faridah and Nurul huda, 1999). In Indonesia, especially the people of South Sumatra using the stem bark of the $T$. indica for the treatment of kidney stones (Muharni, Fitriya \& Farida, 2016; Ong \& Nordiana, 1999) and the leaves used for hypercholesterolemia (Samitra \& Rozi, 2017). In India was used for the treatment of dysentery, hepatitis, diuretics, fever and fatigue (Lima, Lemos \& Conserva, 2014).

The phytochemical test of the methanol extract of the stem bark of $T$. indica showed positive containing triterpenoid, steroid, saponin, flavonoid and phenolic compounds. The efficacy of a medicinal plant, closely related to secondary metabolites contained in these plants (Sangi, Runtuwene, Simbala \& Makang, 2008; Yustian et al., 2012). Based on the literature study, flavonoid compounds in the form of 5,7-dihydroxy 8metoxyflavone (wogonin), 5, 7,8-tryhydroxy flavone, isocutellarein methyl ether, kaemferol, quercetin, and tetrocrisin from the leaves of $T$. indica (Dogarai, 2011). Wogonin compound was reported active as antibacterial (Lima et al., 2014) and this compound also found from the fruit extract (Fitriya, Anwar \& Sari, 2009). Another chemical compound that has been reported in the leaves is betulinic acid, $\beta$-sitosterol, and lupeol. Betulinic acid, also reported from the stem of T.indica (Dogarai, 2011; Abdullah, Ismail, Jamaludin \& Hashim, 2013; Harrison, Sia \& Sim, 1994). T. indica also reported having various biological activity such as anti-HIV, antidiabetic, antibacterial, and anti-inflammation (Lima et al., 2014; Hasan et al., 2017, Ahmed et al., 2012; Ragesh, Suja, Vilash, Aneeshkumar \& Rajasekharan, 2016). Based on literature studies, information on the chemical content, especially in the stem of $T$. indca is still very limited. Muharni, Elfita, Adillah, Yohandini, \& Julinar (2018) has been reported the 
wogonin compound from the ethyl acetate extract. In this paper, we will report the isolation and characterization of two compounds from the nhexane extract of stem bark of $T$. indica.

\section{EXPERIMENTAL SECTION Materials}

The materials: The stem bark simplicia of $T$. indica.The fresh stem bark of T.indica was collected in January 2018 from Musi Banyuasin South Sumatera Indonesia and identified by Dr. Laila Hanum (number specimen VIC 2702), Head of the Botany Laboratory, University of Sriwijaya. The stem bark $(2 \mathrm{~kg})$ is cut into pieces and then dried at room temperature after that the stem bark was ground until fine so that obtained the dried powder. Material for isolation: $n$-hexane, ethyl acetate, methanol, acetone pa, chlotoform p.a, cerium sulphate, silica gel G 60 (70-230 mesh), Thin Layer Chromatography (TLC) plate 60G $F_{254}$ Merck (Art 5554). All technical quality solvents were distilled before used.

\section{Instrumentation}

Melting point was determined by Gallen Camp melting point apparatus. UV spectrum was recorded on spectrophotometer ultraviolet Beck DU-7500. The $\mathrm{IR}(\mathrm{KBr})$ spectrum was recorded on Perkin Elmer-FTIR spectrometer, Shimadzu UV-168A. The 'H-NMR and ${ }^{13} \mathrm{C}-\mathrm{NMR}$ spectra were recorded on Agilent DD2 $\left({ }^{1} \mathrm{H}\right.$ NMR500 MHz, ${ }^{13} \mathrm{C}-\mathrm{NMR} 125 \mathrm{MHz}$ ), ultra-violet lamps used CAMAG $254 \mathrm{~nm}$, Thin Layer Chromatography (TLC) was performed with silica gel $60 G \mathrm{~F}_{254}$ using Merck (Art.5554) and spots were visualized by cerium sulfate vapors and ultra violet light.

\section{Extraction and Isolation}

The dried powdered plant material about $550 \mathrm{~g}$ was macerated with $n$-hexane for 24 hours The extraction process were repeated three times. The $n$ hexane extract was concentrated by Rotary evaporator at about $50^{\circ} \mathrm{C}$ and obtained crude nhexane extract $(250 \mathrm{mg})$. The crude $n$-hexane $(250$ $\mathrm{mg}$ ) was dissolved in the of acetone and adsorbed on $500 \mathrm{mg}$ silica gel (70-230 mesh), stirred evenly and the slurry formed was allowed to dry. Crude nhexane extract was separated by column chromatography technique using silica gel G60 (70 $-230 \mathrm{mesh}) 60 \mathrm{~g}$ as stationary phase. The column $(60 \mathrm{~cm} \times 2 \mathrm{~cm})$ was prepared by place cotton at the bottom of the column. The slurry of silica in $n$ hexane was poured into the column. The silica slurry were compacted by flowing $n$-hexane solvent repeatedly. The Extract has been preparate was charged into the column. The column was first eluted with $n$-hexane and then with the solvent $n$-hexane: ethyl acetate $(9: 1$ to $3: 7)$. The fraction of $10 \mathrm{~mL}$ were collected in bottles vial and evaporated.TLC analysis toidentify the component with UV lamp and cerium sulfate to the component viewer. Vials showed same TLC patters were combined into one fraction, and obtained 4 fractions, F1 (vials 1-2, $52 \mathrm{mg}$ ), F2 ( vials $3-5.81 \mathrm{mg}$ ), F3 (vials $6-15.32 \mathrm{mg}$ ) dan F4 (vials $15-20.15 \mathrm{mg}$ ).

Fraction F1 $(52 \mathrm{mg})$ was again separated and purified by open column chromatography using elvent $n$-hexane: ethyl acetate (9: 1 and 8: 2) 150 $\mathrm{mL}$ respectively. Base on TLC patters was combined into one sub fraction and obtained 2 subfractions $F_{1.1}$ $(17 \mathrm{mg})$, and $F_{2.2}(22 \mathrm{mg})$. The subfraction $\mathrm{Fl} .1$ which on concentration yielded a residue which was after purification with $n$-hexane solvent was obtained pure compound white crystalline $9 \mathrm{mg}$ (1). Fraction F2 after being separated and purified by open column chromatography method, based on TLC patters into combined one subfraction and obtained 3 subfractions F2.1 (28 mg), F2.2 (12 mg), and F2.3 $(24 \mathrm{mg})$. Subfraction F2.1 after purification with $\mathrm{n}$ hexane solvent was obtained colorless amorphous powder $22 \mathrm{mg}$ (2). The TLC patters of the two isolated compounds using cerium sulfate showed one spot in various eluents.

\section{Characterization of the compounds}

The structure of compounds was determined the structure using UV, IR, ${ }^{1} \mathrm{H}-\mathrm{NMR},{ }^{13} \mathrm{C}-\mathrm{NMR}$ and DEPT spectroscopy.

\section{RESULTS AND SISCUSSION}

Compound 1 is white crystalline, m.p 135 $137^{\circ} \mathrm{C}$. Spektrum UV $(\mathrm{MeOH})$ indicates maximum absorption at $\lambda_{\max } 206 \mathrm{~nm}$. The UV spectrum indicates that the isolated compound is a steroid group because there is no visible absorption for the chromophore group. IR absorptions bands appeared at IR Spectroscopic analysis, the observed absorption bands are bands appeared at $\left(\lambda_{\max } \mathrm{cm}^{-1}\right) 3423 \mathrm{~cm}^{-}$ '(O-H stretching), 2935 and $2886 \mathrm{~cm}^{-1}$ (aliphatic C$\mathrm{H}$ stretching asymmetric and symmetric), 1463 and $1377 \mathrm{~cm}^{-1}$ (cyclic( $\left.\mathrm{CH} 2\right)_{\mathrm{n}}$ bending), and the absorption frequency at $1056 \mathrm{~cm}^{-1}$ (C-O). The absorption frequencies in IR spectrum show similarity the absorption frequencies for $\beta$-sitosterol.

${ }^{1} \mathrm{H}-\mathrm{NMR}\left(\left(\mathrm{CD}_{3}\right)_{2} \mathrm{CO}, 500 \mathrm{MHz}\right) \delta \mathrm{H} \mathrm{ppm}$ and ${ }^{13} \mathrm{C}$ NMR $\left(\left(\mathrm{CD}_{3}\right)_{2} \mathrm{CO}, 125 \mathrm{MHz}\right) \delta_{\mathrm{c}} \mathrm{ppm}$ for compound 1 can see Table 1. The proton ${ }^{1} \mathrm{H}-\mathrm{NMR}$ spectrum showed the proton of $\mathrm{H}-3$ appeared as $\delta_{\mathrm{H}} 3.30 \mathrm{ppm}$ $(1 \mathrm{H}, \mathrm{m})$, and signal for vinylic proton appeared at $\delta_{\mathrm{H}}$ $5.20(1 \mathrm{H}, \mathrm{m})$ indicating the presence of one methine group that is characteristic of $\beta$-sitosterol. 'H-NMR spectrum of compound 1 showed the presence of 6 high intensity peaks at $\delta_{H} 0.71 ; 0.81 ; 0.83 ; 0.86$; 0.96 ; and $1.02 \mathrm{ppm}$, indicating the presence of six methyl groups (Figure 1). From the 6 methyl proton signals, two between shown as double signal supported by 'H-NMR spectrum and the DEPT spectrum which is only shows 6 methyl carbon signals. The ${ }^{13} \mathrm{C}-\mathrm{NMR}$ spectra shown signals at $\delta_{c}$ 141.5 and $120.7 \mathrm{ppm}$ recognizable as signal which 
assigned at C-5 and C-6 double bonds respectively in $\beta$-sitosterol. Spectra ${ }^{13} \mathrm{C}-\mathrm{NMR}$ compound 1 show twenty nine carbon signal. To determined the type of carbon, methyl methylene, methine or quaternary carbon can be used DEPT spectrum (Figure 2). Base on DEPT spectrum show consists of six methyls at $\delta_{C} 11.3 ; 11.4 ; 18.3 ; 18.4 ; 18.9$ and 19.20 ppm, nine methylenes at $\delta_{c} 37.4 ; 31.6 ; 42.4 ; 31.7 ; 22.9$; $39.8 ; 24.1 ; 28.1 ; 20.9 \mathrm{ppm}$, eleven methines at $\delta_{c}$ $70.8 ; 120.7 ; 36.0 ; 50.3 ; 56.8 ; 56.0 ; 40.5 ; 45.8$; $33.8 ; 25.9 ; 31.9$ and three quaternary carbons at $\delta_{c} 141.5 ; 36.4$ and 42.20 ppm. Signal carbon appeared at $\delta_{C} 70.3$ characteristics for C-3.

Table 1. ${ }^{1} \mathrm{H}$ and ${ }^{13} \mathrm{C}$ NMR chemical shift values for compound $1^{a}\left({ }^{1} \mathrm{H}-500 \mathrm{MHz},{ }^{13} \mathrm{C}-125 \mathrm{Mhz}\right.$, in $\left.\mathrm{CDCl}_{3}\right)$ and $\beta$-sitosterol ${ }^{\mathrm{b}}\left({ }^{1} \mathrm{H}-400 \mathrm{MHz}^{13} \mathrm{C}-100 \mathrm{Mhz}\right.$, in $\left.\mathrm{CDCl}_{3}, \mathrm{ppm}\right)($ Pierre \& Moses, 2015)

\begin{tabular}{|c|c|c|c|c|c|}
\hline C No. & $\delta C(p p m)^{b}$ & $\delta C(p p m)^{a}$ & $\delta \mathrm{H}(\mathrm{ppm})^{\mathrm{b}}$ & $\delta \mathrm{H}(\mathrm{ppm})^{a}$ & DEPT \\
\hline 1 & 36.8 & 37.4 & & & $\mathrm{CH}_{2}$ \\
\hline 2 & 29.2 & 31.6 & & & $\mathrm{CH}_{2}$ \\
\hline 3 & 78.6 & 70.8 & $3.51(1 \mathrm{H}, \mathrm{m})$ & $3.38(1 \mathrm{H}, \mathrm{m})$ & $\mathrm{CH}$ \\
\hline 4 & 39.3 & 42.4 & & & $\mathrm{CH}_{2}$ \\
\hline 5 & 140.4 & 141.5 & & & C \\
\hline 6 & 121.2 & 120.7 & $5.31(1 \mathrm{H}, \mathrm{t})$ & $5.31(1 \mathrm{H}, \mathrm{t})$ & $\mathrm{CH}$ \\
\hline 7 & 31.4 & 31.7 & & & $\mathrm{CH}_{2}$ \\
\hline 8 & 31.3 & 36.0 & & & $\mathrm{CH}$ \\
\hline 9 & 49.6 & 50.3 & & & $\mathrm{CH}$ \\
\hline 10 & 36.4 & 36.4 & & & C \\
\hline 11 & 20.6 & 22.9 & & & $\mathrm{CH}_{2}$ \\
\hline 12 & 38.3 & 39.8 & & & $\mathrm{CH}_{2}$ \\
\hline 13 & 41.8 & 42.2 & & & C \\
\hline 14 & 56.1 & 56.0 & & & $\mathrm{CH}$ \\
\hline 15 & 23.8 & 24.1 & & & $\mathrm{CH}_{2}$ \\
\hline 16 & 27.8 & 28.1 & & & $\mathrm{CH}_{2}$ \\
\hline 17 & 55.4 & 56.8 & & & $\mathrm{CH}$ \\
\hline 18 & 11.6 & 11.4 & $1.03(3 \mathrm{H}, \mathrm{s})$ & $1.02(3 \mathrm{H}, \mathrm{s})$ & $\mathrm{CH}_{3}$ \\
\hline 19 & 19.1 & 19.2 & $0.71(3 \mathrm{H}, \mathrm{s})$ & $0.71(3 \mathrm{H}, \mathrm{s})$ & $\mathrm{CH}_{3}$ \\
\hline 20 & 35.4 & 40.5 & & & $\mathrm{CH}$ \\
\hline 21 & 18.6 & 18.9 & $0.91(d)$ & $0.96(3 \mathrm{H}, d)$ & $\mathrm{CH}_{3}$ \\
\hline 22 & 33.3 & 33.8 & $4.98(\mathrm{~m})$ & $5.011 \mathrm{H}, \mathrm{dd})$ & $\mathrm{CH}$ \\
\hline 23 & 25.4 & 25.9 & $5.141(\mathrm{H}, \mathrm{m})$ & $5.21(1 \mathrm{H}, \mathrm{dd})$ & $\mathrm{CH}$ \\
\hline 24 & 45.1 & 45.8 & & & $\mathrm{CH}$ \\
\hline 25 & 28.6 & 31.9 & & & $\mathrm{CH}$ \\
\hline 26 & 19.7 & 18.4 & $0.80(3 \mathrm{H}, d)$ & $0.81(3 \mathrm{H}, \mathrm{d})$ & $\mathrm{CH}_{3}$ \\
\hline 27 & 18.9 & 18.3 & $0.82(3 \mathrm{H}, \mathrm{d})$ & $0.83(3 \mathrm{H}, d)$ & $\mathrm{CH}_{3}$ \\
\hline 28 & 22.1 & 20.9 & & & $\mathrm{CH}_{2}$ \\
\hline 29 & 11.7 & 11.3 & $0.83(3 \mathrm{H}, t)$ & $0.86(3 \mathrm{H}, t)$ & $\mathrm{CH}_{3}$ \\
\hline
\end{tabular}

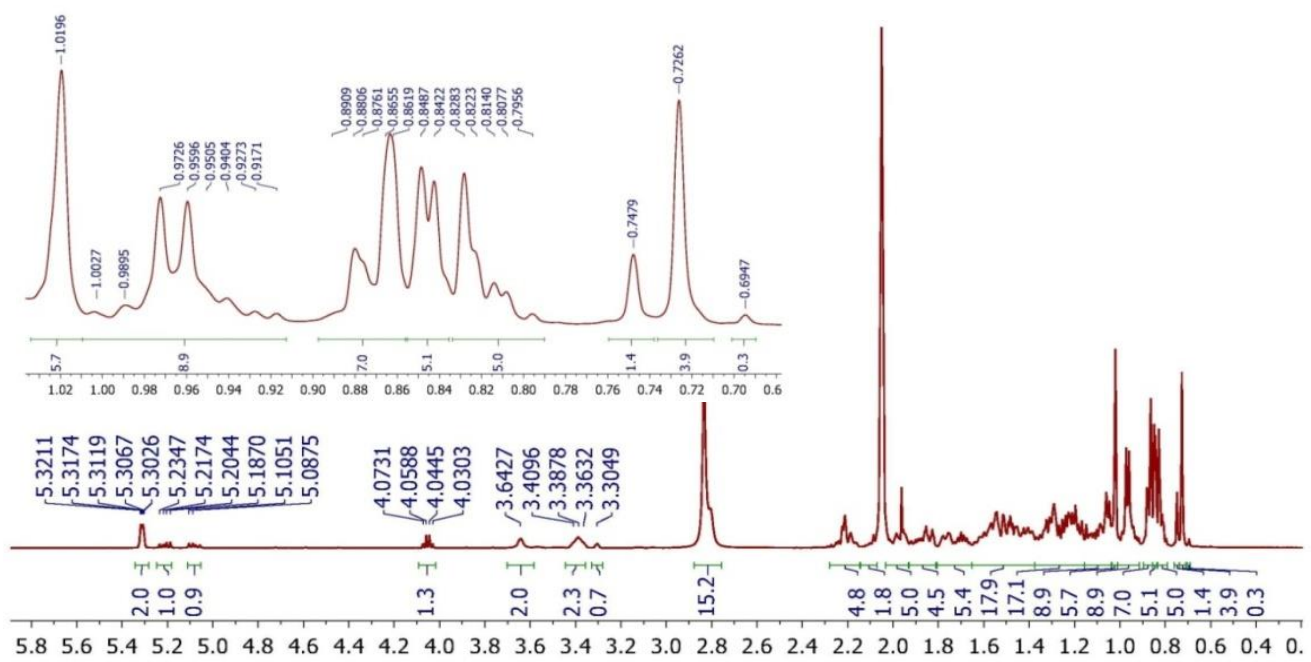

Figure 1. Spectrum 'H NMR $\beta$-sitosterol (1) 

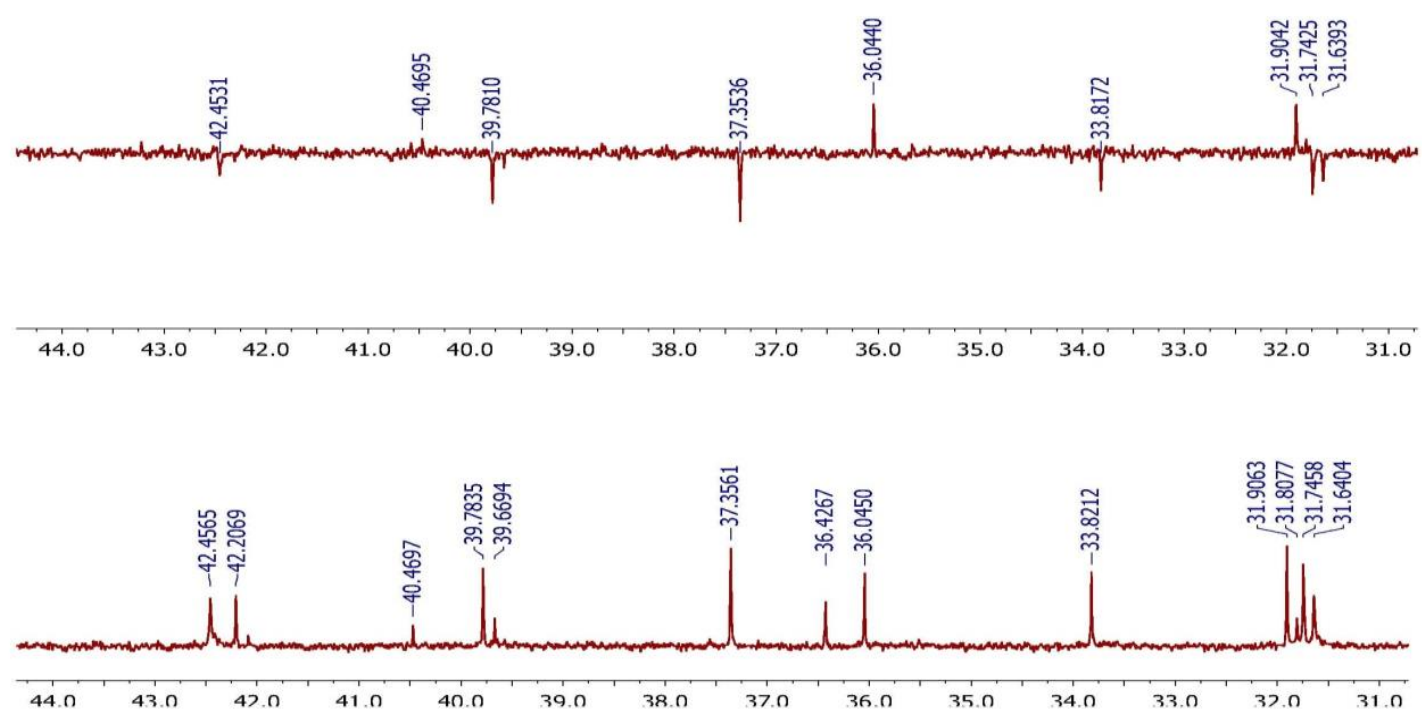

Figure 2. Spektrum DEPT $\beta$-sitosterol (1)
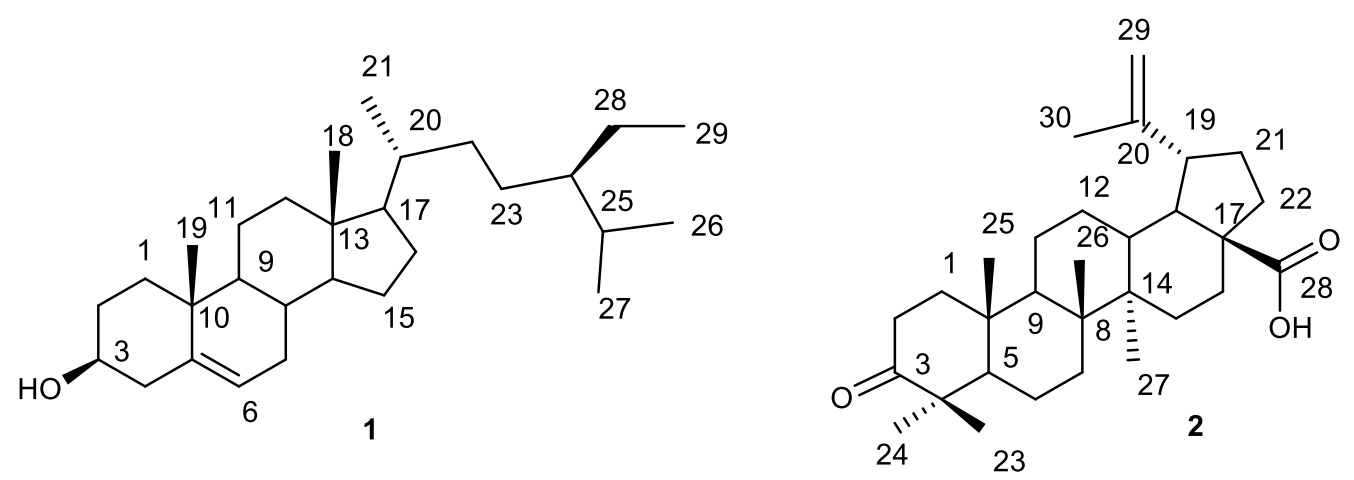

Figure 3. Structure $\beta$-sitosterol (1) and betulonic acid (2)

The UV, IR, 'H NMR, and ${ }^{13} \mathrm{C}$ NMR spectra data of compound 1 has been comparison with literature data of $\beta$-sitosterol and show the structure of compound 1 is $\beta$-sitosterol. (Figure 3 ). The $\beta$ sitosterol has also been previously reported from $\mathrm{MeOH}$ extract leaves of T.indica but for the first time reported from the extract of stem bark of $T$. Indica.

Compound $\mathbf{2}$ is colorless amorphous powder m.p $291-293^{\circ} \mathrm{C}$. UV spectrum showed no patterns above $\lambda_{\max } 210 \mathrm{~nm}$. IR spectrum appeared absorption band at $3338 \mathrm{~cm}^{-1}(\mathrm{O}-\mathrm{H}$ streching), which is strengthened with the absorption frequency at 1037 (C-O). IR spectrum also appeared absorbtion at 2935 and $2886 \mathrm{~cm}^{-1}$ (C-H aliphatic streching), $1641 \mathrm{~cm}^{-1}\left(\mathrm{C}=\mathrm{C}\right.$ isolated ) $1456 \mathrm{~cm}^{-1}$ (cyclic $(\mathrm{CH} 2)_{\mathrm{n}}$ bending and $1381 \mathrm{~cm}^{-1}$ (gem dymethyl $\left.-\mathrm{CH}\left(\mathrm{CH}_{3}\right)_{2}\right)$. In the IR spectra of this compound the present several vibrations characteristic of the triterpenoid compound.

The ${ }^{1} \mathrm{H}-\mathrm{NMR}$ spectrum of the isolated compound 2 (Figure 4) shows signal peaks that accumulate below the $\delta_{H} 3 \mathrm{ppm}$ area and also the peak for the dominant methyl signals. This indicates that the isolated compounds are triterpenoid or steroid groups. The widening of the ${ }^{1} \mathrm{H}$ - NMR spectrum in the area of $\delta_{H}$ 0.85-1.80 ppm showed six signal methyl groups at $\delta_{\mathrm{H}} 0.95 \mathrm{ppm}(3 \mathrm{H}, \mathrm{s}) ; 1.00(6 \mathrm{H}, \mathrm{s})$; $1.04(6 \mathrm{H}, b r s) ; \delta_{\mathrm{H}} 1.70 \mathrm{ppm}(3 \mathrm{H}, \mathrm{s})$. The signal at $4.59(1 \mathrm{H}$, brs $)$ and $4.72(1 \mathrm{H}, \mathrm{brs})$ for two signal vinylic protons. The ${ }^{13} \mathrm{C}-\mathrm{NMR}$ spectrum (Figure 5) shows a characteristic spectrum for triterpenoids where the signals appear to accumulate below $\delta_{C} 60$ ppm which is a signal for $\mathrm{C}, \mathrm{CH}, \mathrm{CH}_{2}$ and $\mathrm{CH}_{3}$ from cyclo aliphatic from triterpenoid.

The ${ }^{13} \mathrm{C}-\mathrm{NMR}$ spectrum shows 30 signal (Table 2), 4 signal appeared on $\delta_{c} 100 \mathrm{ppm}$ at $\delta_{c} 110.0 ; \delta_{c}$ $151.6 \mathrm{ppm}$ for $\mathrm{C}=\mathrm{C}$ and two signal at $\delta_{\mathrm{C}} 177.5 \mathrm{ppm}$ ( $\mathrm{C}=\mathrm{O}$ acid) and $\delta_{\mathrm{c}} 216.4 \mathrm{ppm}(\mathrm{C}=\mathrm{O}$ ketone). In the ${ }^{13} \mathrm{C}-\mathrm{NMR}$ spectrum no signal appears at $\delta_{C}$ 73-75 ppm which the characteristics for signal C-3 which bind $\mathrm{OH}$ which is commonly found in triterpenoid compounds.To determine the type of carbon determined from the DEPT 135 spectrum so that it can be determined the amount of $C$ 
quaternary, $\mathrm{CH}$ (methine), $\mathrm{CH}_{2}$ (methylene), and $\mathrm{CH}_{3}$ (methyl). In the DEPT 135 spectrum, the $\mathrm{CH}_{3}$ and $\mathrm{CH}$ signals appear upward, the $\mathrm{CH}_{2}$ signal downwards and the $\mathrm{C}$ quartener signal does not appear. DEPT Spectrum show 6 signal methyl at $14.9 ; 16.3$; $16.4 ; 19.5 ; 21.3$ and $30.1 \mathrm{ppm}), 11$ methylene signal at $\delta_{c}(20.4 ; 22.2 ; 26.4 ; 30.5 ; 31.3 ; 32.7$; $34.4 ; 34.5 ; 37.5 ; 40.2$ and 110.0 ppm), 5 methine signal at $\delta_{C}(39.1 ; 47.9 ; 49.8 ; 50.6$; and $55.5 \mathrm{ppm})$ and 8 signal $C$ quaternary at $\delta_{C}(37.6 ; 41.5 ; 43.3$; $47.7 ; 56.8 ; 15.6 ; 177.5$; and $216.4 \mathrm{ppm})$.

The UV, IR, ${ }^{1} \mathrm{H}-\mathrm{NMR}$, and ${ }^{13} \mathrm{C}-\mathrm{NMR}$ spectra data and their comparison with those described in literature (Liv et al., 2012) showed in Table 2. Base on data in Table 2 the structure of compound 2 is betulonic acid (Figure 3 ). Comparison of ${ }^{13} \mathrm{C}-\mathrm{NMR}$ data in Table 2 shows that the isolated compound show a chemical shift value that is almost the same as the comparison data, while there is a slight difference in chemical shift value because the solvent used to isolated compound of solvent $\left(\mathrm{CD}_{3}\right)_{2} \mathrm{CO}$ which is different from the literature data that used solvents $\mathrm{CDCl}_{3}$.

Liv et al., (2012) reported that betulonic acid compound from root extracts of Belamcanda chinensis (L.) which had biological activity as antitumor. According to Shabana, El Sayed, Yousif \& Sleem, (2011) in Harpephyllum caffrum leaves also contain betulonic acid which is active as an antioxidant and antitumor. Betulonic acid alsowas found by Zhang, Li, Fong, \& Soejarto, (2016) in leaves of Vatica cinerea King (Dipterocarpaceae) which showed anti-HIV activity. Betulonic acid has been widely reported from other species but for the first time reported from the extract of stem bark of $T$. indica.

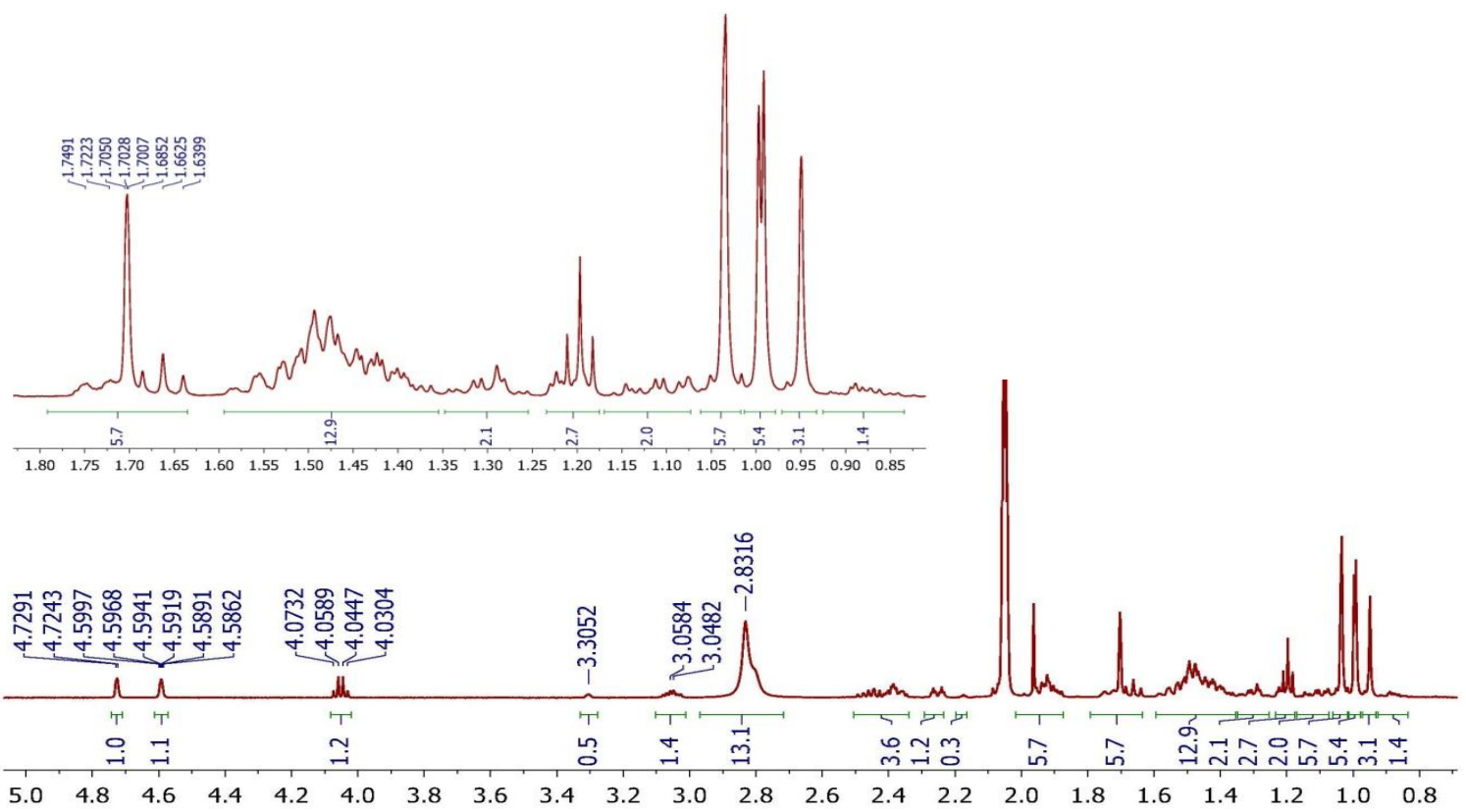

Figure 4. Spectrum 'H NMR betulonic acid (2)

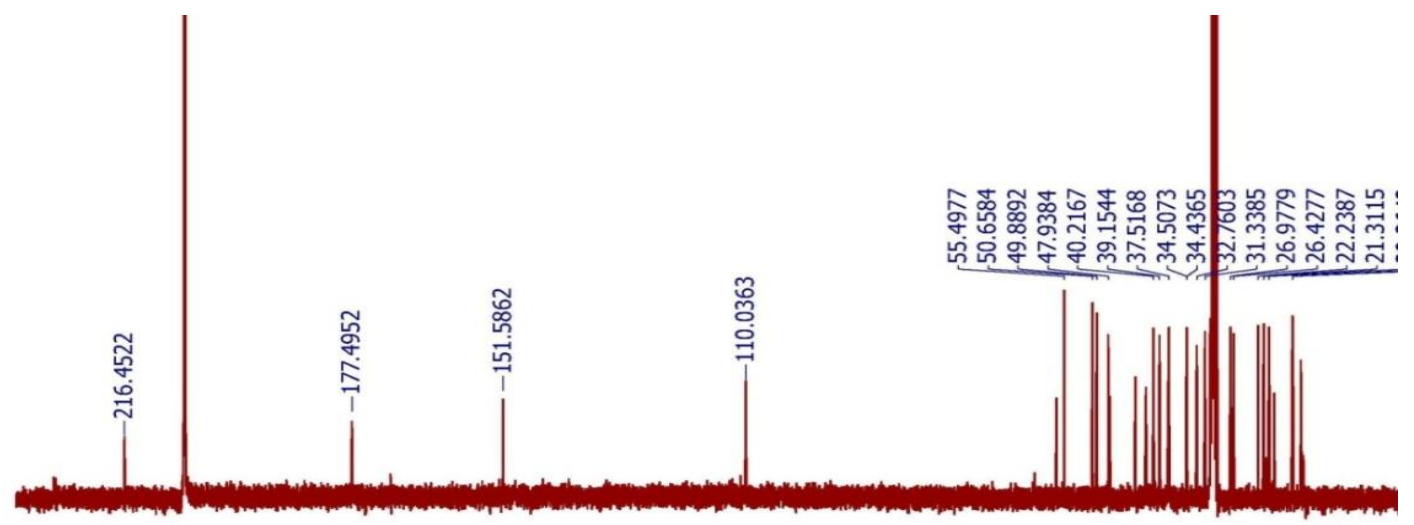

$\begin{array}{llllllllllllllllllllllll}230 & 220 & 210 & 200 & 190 & 180 & 170 & 160 & 150 & 140 & 130 & 120 & 110 & 100 & 90 & 80 & 70 & 60 & 50 & 40 & 30 & 20 & 10 & 0\end{array}$

Figure 5. Spectrum ${ }^{13} \mathrm{C}$ NMR betulonic acid (2) 
Table2. ${ }^{1} \mathrm{H}$ and ${ }^{13} \mathrm{C}$ NMR chemical shift values for compound $2^{a}\left({ }^{1} \mathrm{H}-500 \mathrm{MHz},{ }^{13} \mathrm{C}-125\right.$ $\mathrm{MHz}$, in $\left.\left(\mathrm{CD}_{3}\right)_{2} \mathrm{CO}\right)$ and betulonic acid ${ }^{1} \mathrm{H}-400 \mathrm{MHz},{ }^{13} \mathrm{C}-100 \mathrm{MHz}^{2}$ in $\mathrm{CDCl}_{3}$, ppm)(Liv et al., 2012)

\begin{tabular}{|c|c|c|c|}
\hline C No. & $\delta C(p p m)^{b}$ & $\delta C(p p m)^{a}$ & DEPT \\
\hline 1 & 39.6 & 40.2 & $\mathrm{CH}_{2}$ \\
\hline 2 & 34.1 & 34.1 & $\mathrm{CH}_{2}$ \\
\hline 3 & 218.5 & 216.4 & C \\
\hline 4 & 47.4 & 41.5 & C \\
\hline 5 & 54.9 & 55.5 & $\mathrm{CH}$ \\
\hline 6 & 19.6 & 20.4 & $\mathrm{CH}_{2}$ \\
\hline 7 & 33.6 & 34.4 & $\mathrm{CH}_{2}$ \\
\hline 8 & 40.6 & 43.3 & C \\
\hline 9 & 49.9 & 50.7 & $\mathrm{CH}$ \\
\hline 10 & 36.9 & 37.7 & C \\
\hline 11 & 21.4 & 22.2 & $\mathrm{CH}_{2}$ \\
\hline 12 & 25.5 & 26.4 & $\mathrm{CH}_{2}$ \\
\hline 13 & 38.5 & 39.1 & $\mathrm{CH}$ \\
\hline 14 & 42.5 & 47.7 & $C$ \\
\hline 15 & 29.7 & 30.5 & $\mathrm{CH}_{2}$ \\
\hline 16 & 32.1 & 32.7 & $\mathrm{CH}_{2}$ \\
\hline 17 & 56.4 & 56.8 & C \\
\hline 18 & 49.2 & 49.9 & $\mathrm{CH}$ \\
\hline 19 & 47.0 & 47.9 & $\mathrm{CH}$ \\
\hline 20 & 150.4 & 151.6 & C \\
\hline 21 & 30.6 & 31.3 & $\mathrm{CH}_{2}$ \\
\hline 22 & 37.1 & 37.5 & $\mathrm{CH}_{2}$ \\
\hline 23 & 26.7 & 26.7 & $\mathrm{CH}_{3}$ \\
\hline 24 & 21.0 & 21.3 & $\mathrm{CH}_{3}$ \\
\hline 25 & 15.8 & 16.3 & $\mathrm{CH}_{3}$ \\
\hline 26 & 16.0 & 16.4 & $\mathrm{CH}_{3}$ \\
\hline 27 & 14.6 & 14.9 & $\mathrm{CH}_{3}$ \\
\hline 28 & 182.4 & 177.5 & C \\
\hline 29 & 109.8 & 110.0 & $\mathrm{CH}_{2}$ \\
\hline 30 & 19.4 & 19.5 & $\mathrm{CH}_{3}$ \\
\hline
\end{tabular}

\section{CONCLUSIONS}

Two compounds $\beta$-sitosterol (1) and betulonic acid (2) were successfully isolated and identified from the $n$-hexane extracts of stem bark of Tetracera indica. betulonic acid was first reported from $T$. indica.

\section{ACKNOWLEDGMENTS}

The authors are grateful to Sriwijaya University which research grant competition 2017. for their financial supported this research. Thank are also given to Dr. Laila Hanum (Head of the Botany Laboratory, University of Sriwijaya Indonesia) for identification of the plant material and Prof. Dr. Yana Maulana Syah (Departement of Chemistry Institute Technology Bandung, Indonesia) for data UV, IR and NMRspectroscopy.

\section{REFFERENCES}

Abdullah, F., Ismail, N. H., Jamaludin, F., \& Hashim, S. N. A. M. (2013). Xanthine oxidase inhibitory activity of Tetracera indica. The Open Conference Proceedings Journal. 4 (1), 93-94.
Ahmed, Q. U., Dogarai, B. B. S., Amiroudine, M. Z., Taher, M., Latip, J., Umar, A., \& Muhammad, B. Y. (2012). Antidiabetic activity of the leaves of Tetracera indica Merr (Dilleniaceae) invivo and invitro.Journal of Medical Plants Reasearch, 6 (49),5915-5918.

Dogarai, B.B.S.(2011). Phyłochemical and antidiabetic activity investigations of Tetracera. Thesis, International Islamic University Malaysia.

Faridah, H. I., \& Nurulhuda, H. (1999). The use of medicinal plant species by the temuan tribe of Ayer Hitam Forest. Selangor Peninsular Malaysia. Pentarika Journal Tropical Agriculture. 22(2), 85-94.

Fitriya, Anwar, L.\& Sari, F.(2009). Identifikasi flavonoid dari buah tumbuhan mempelas. Jurnal Penelitian Sains, 12 (3), 1-5.

Harrison, L. J., Sia, G. L., \& Sim, K. Y. (1994). 5,7dihydroxy-8-methoxy flavone from Tetracera indica. Planta Medica, 60 (1), 493-494.

Hasan, M. M., Ahmed, Q. U., Siti, Z. M. S., Latip, J., M. Taher, Tengku, M. F. S., Nazira, M. S., A. M. 
Alhassan, \& Zakaria, Z. A. (2017). Flavonoids from Tetracera indica Merr. Induce adipogenesis and exertglucoseuptake Activities in 3T3-L1 adipocytecells. BMC Complementary and Alternative Medicine. 17: 431.

Hoogland, R. D. (1953). The GenusTetracera (Dilleniaceae) in The Eastern OldWorld. Reinwardtia. 2 (1), 185-224.

Lima, C. C., Lemos, R. P. L., \&Conserva, L. M. (2014). Dilleniaceae Family: An overview of Its ethno medicinal uses, biological and phytochemical profile. Journal of Pharmacognosy and Phytochemistry. 3 (2), 183-196.

Liu, M., Yang, S., Jin, L., Hu, D., Wu, Z., \& Yang, S. (2012). Chemical constituents of the ethyl acetate extract of Belamcanda chinensis(L.) DC root sand their anti tumor activities. Molecules, 17, 6156-6169.

Muharni, Fitrya, \& Farida, S.(2016). Skrining fitokimia, aktivitas antioksidan dan antibakteri ekstrak tumbuhan obat Etnis Musi di Kabupaten Musi Banyuasin Sumatera Selatan. Laporan penelitian Ristoja 2016 Kementrian Kesehatan RI Badan Penelitian dan Pengembangan Kesehatan Balai Besar Penelitian dan PengembanganTanaman Obat dan Obat Tradisional.

Muharni, Elfita, Adillah, R., Yohandini, H., \& Julinar. (2018). Flavon Compound from The Ethyl Acetate Extract of The Stem of Supit (Tetracera indica Merr.). Molekul, 13(1), 38 - 47.

Ong, H. C., \& Nordiana, M. (1999). Malay EthnoMedico Botany in Machang, Kelantan, Malaysia. Fitoterapia. 70 (1), 502-513.

Piere, L.L., \& Mosess, N. M. (2015). Isolation and Characterisaion of Stigmasterol and $\beta$ Sitosterol from Odontonema strictum
(Acanthaceae). Journal of Innovations in Pharmaceuticals and Biological Sciences, 2(1), 88-96.

Ragesh, R. N., S. R. Suja, V. Vilash, A. L. Aneeshkumar, \& Rajasekharan, S. (2016). Pharmacognostic Standardisation and Phytochemical Analysis of Tetracera akara (Burm. f.) Merr. Journal of Traditional and Folk Practices,04 (2), 79-95.

Sangi, M., M. R. J. Runtuwene, H.E.I. Simbala, \& V.M.A. Makang. (2008). Analisis Fitokimia Tumbuhan Obat di Kabupaten Minahasa Utara. Journal Chemical Program. 1(1), 47-53.

Samitra, D., \& Rozi, Z. F. (2017). Pengaruh Air Rebusan Daun Mempelas (Tetracera indica Merr.) terhadap Kadar Kolesterol Darah Mencit. Scripta Biologica, 197-199.

Shabana, M. M., El Sayed, A. M., Yousif, M. F., \&Sleem, A. A. (2011). Bioactive Constituents from Harpephyllum caffrum Bernh and Rhus coriaria L. Pharmacognocy Magazine. 7(28):298-306.

Widjaja, E A., Rahayuningsih, Y., Rahajoe, J. S., Ubaidillah, R., Maryanto, I., Walujo, E. B., \&Semiadi, G. (2014). Kekinian Keanekaragaman Hayati Indonesia. LIPI Press: Kementerian Lingkungan Hidup dan Bappenas.

Yustian, I.,Muharni, Sukarmi, S., Zulaicha, \&Arbi, M. (2012). Riset Khusus Eksplorasi Pengetahuan Lokal Etnomedisin dan Tumbuhan Obat di Indonesia Berbasis Komunitas (Wilayah Musi II). Kemenkes RI.

Zhang, H. J., Li, W. F., Fong, H. H. S., \&Soejarto, D. D. (2016). Review Discovery of Bioactive Compounds by the UIC-ICBG Drug Discovery Program in the 18 Years Since 1998. Molecules, 21, 1448. 